\title{
A RHETORICAL ANALYSIS OF JEREMIAH 7:1-15
}

\author{
Michael Avioz
}

\begin{abstract}
Summary
This article is a rhetorical study of Jeremiah 7:1-15. It attempts to show that a rhetorical analysis of Jeremiah helps the reader to understand the different parts of the speech correctly, to discover what was mentioned and what was not mentioned in it, and to identify the target audience and the methods of persuasion used by the prophet. This is not merely a literary analysis of Jeremiah's speech, but primarily a critical examination of how Jeremiah planned to deliver his words to the audience. My analysis concludes that Jeremiah's speech is planned and well organised, and that all its parts logically interconnect. Jeremiah uses many traditions from the past, and on the basis of these traditions, presents new arguments.
\end{abstract}

\section{Introduction}

Jeremiah's speech in the temple (Jer. 7:1-15) is one of the most impressive in the Hebrew Bible. However, most studies on the subject deal with the distinction between the redactional layers in the chapter, and its relationship to chapter 26 . Only a few pay attention to its rhetorical dimension. ${ }^{2}$ As a result, the speech becomes a collection of

\footnotetext{
${ }^{1}$ This study was funded by Beit Shalom Fund of Japan. I thank the fund managers for their support. I also wish to thank Prof. Yehoshua Gitay from the University of Cape Town for reading and commenting on a first draft of this paper.

2 See for example: W. McKane, A Critical and Exegetical Commentary on Jeremiah (2 vols; Edinburgh: T. \& T. Clark, 1986): 158-69; D. R. Jones, Jeremiah (NCB; London: Marshall Pickering; Grand Rapids: Eerdmans, 1992); Else K. Holt, 'Jeremiah's Temple Sermon and the Deuteronomists: An Investigation of the Redactional Relationship between Jeremiah 7 and 26', JSOT 36 (1986): 73-87; SaMoon Kang, 'The Authentic Sermon of Jeremiah in Jeremiah 7:1-20', in Texts, Temples, and Traditions: A Tribute to Menahem Haran, ed. Michael V. Fox et al.
} 
aphorisms connected only by the act of editing. We follow George Kennedy who analyses the text:

... as we have it, whether the work of a single author or the product of editing, and looks at it from the point of view of the author's or editor's intent, the unified results, and how it would be perceived by an audience of near contemporaries. ${ }^{3}$

In his book, Saviours and Prophets, ${ }^{4}$ Zeev Weisman writes the following:

The canonical prophets' charismatic test lay not so much in whether they succeeded in predicting the future, but in whether they possessed the proficiency and power with which to persuade their audience of the truth of their messages.

As a continuation of these words, I will attempt to show in this study that research written on the subject of rhetoric can make a significant contribution to understanding Jeremiah's speech in the temple. ${ }^{5}$

(Winona Lake, IN: Eisenbrauns, 1996): 147-62; C. J. Sharp, Prophecy and Ideology in Jeremiah: Struggles for Authority in the Deutero-Jeremianic Prose (London/New York: T. \& T. Clark, 2003): 44-54.

3 G. A. Kennedy, New Testament Interpretation Through Rhetorical Criticism (Chapel Hill: University of North Carolina, 1984): 4.

4 Z. Weisman, Saviours and Prophets: Two Aspects of Biblical Charisma (Hebrew; Tel Aviv: Hakibbutz Hameuchad, 2003): 152.

5 The only scholar of the Book of Jeremiah who used the tools of rhetoric as an aid to analysing the speech is Lundbom. However, his analysis of chapter 7 is incomplete, and I disagree with some of his conclusions. See J. R. Lundbom, Jeremiah 1-20 (AB, 21A; Garden City, NY: Doubleday, 1999). See also Lundbom, Jeremiah: A Study in Ancient Hebrew Rhetoric (2nd edn; Winona Lake, IN: Eisenbrauns, 1997). Some scholars used rhetorical criticism for analysing various biblical texts. See G. A. Kennedy, Classical Rhetoric and Its Christian and Secular Tradition From Ancient to Modern Times (2nd, rev. edn; Chapel Hill: University of North Carolina, 1999): 13742; Y. Gitay, 'A Study of Amos's Art of Speech: A Rhetorical Analysis of Amos 3:115', CBQ 42 (1980): 293-309; idem, Isaiah and His Audience: The Structure and Meaning of Isaiah 1-12, Studia Semitica Neerlandica (Assen: Van Gorcum, 1991); idem, Prophecy and Persuasion: A Study of Isaiah 40-48 (Forum Theologiae Linguisticae 14; Bonn: Linguistica Biblica, 1981); Rodney K. Duke, The Persuasive Appeal of the Chronicler: A Rhetorical Analysis (JSOTSup 88; Bible and Literature 25; Sheffield: Almond, 1990); D. Patrick and A. Scult, Rhetoric and Biblical Interpretation (JSOTSup 82; Sheffield: Almond, 1990); Phyllis Trible, Rhetorical Criticism: Context, Method, and the Book of Jonah (Guides to Biblical Scholarship; Minneapolis: Fortress, 1994); P. Dutcher-walls, Narrative Art, Political Rhetoric: The Case of Athaliah and Joash (JSOTSup 209; Sheffield: Sheffield Academic, 1996). 
I follow Miller's definition, ${ }^{6}$ which states that the aim of rhetorical criticism is to determine:

1. The limits of the rhetorical unit to be studied; 2 . The rhetorical situation of the unit, involving persons, events, objects, and relations; 3. The particular problem or issue that is addressed; 4 . The arrangement of the material; 5. The devices of style employed and their function in the process of persuading the unit's audience.

I will attempt to answer the following questions: What were the historical and societal conditions which led to Jeremiah's speech? What is the message of the speech? By what means does Jeremiah put over his message, with the aim of persuading his audience? ${ }^{7}$

\section{Principles of Rhetoric}

Rhetoric indicates typical stylistic devices, such as rhyme, repetitions, the use of language formulae and stylistic variations integrated within the unit (speech), which are used to awaken interest, to accentuate, and to conquer the audience. ${ }^{8}$

The speech model is usually as follows: ${ }^{9}$

$$
\text { Sender } \rightarrow \text { Message } \rightarrow \text { Receiver }
$$

In the case of Jeremiah, however, the model is more complex:

Sender (God) $\rightarrow$ Receiver A (Prophet)

$\rightarrow$ Message $\rightarrow$ Receiver B (People). ${ }^{10}$

6 Douglas Miller, 'What the Preacher Forgot: The Rhetoric of Ecclesiastes', $C B Q 62$ (2000): 215-35, esp. 216. For a similar procedure of rhetorical analysis, see Kennedy, New Testament Interpretation: 33-38.

7 Howard claims that many studies of rhetoric focus only on the literary means, without explaining their function in the speech. See David M. Howard, 'Rhetorical Criticism in Old Testament Studies', BBR 4 (1994): 87-104, esp. 87, 103; Watson and Hauser, Rhetorical Criticism: 18 n. 31. This is especially true regarding Muilenburg's classic study. See James A. Muilenburg, 'Form Criticism and Beyond', JBL 88 (1969): $1-18$.

8 See the references in: Y. Gitay, 'Prophetic Criticism - "What are they Doing?": The Case of Isaiah - A Methodological Assessment', JSOT 26 (2001): 101-27.

9 H. D. Lasswell, 'The Structure and Function of Communication in Society', in The Communication of Ideas, ed. L. Bryson (New York: Harper \& Row, 1948): 203-48. Cf. Edward P. J. Corbett, Classical Rhetoric for the Modern Student (New York: Oxford University, 1971): 2.

10 See M. Weippert, 'Prophetie im Alten Orient', M. Görg and B. Lang, eds, Neues Bibel-Lexikon, Band 3, Lieferung 11 (Zürich: Benziger, 1997): 196-200. 
The significance of this complexity is that the prophet needs to convince the audience that he is God's messenger. Otherwise, he will be suspected of being a false prophet.

The orator's message stands between himself and his target, and he must be attentive to his audience's reactions. His goal is to change accepted opinions, and to accomplish this, his delivery must be persuasive. According to Aristotle, the orator should apply either to the audience's intellect through logical argument, or to the emotions via persuasion. It must be remembered that the orator cannot always bring unequivocal proof for his arguments, as reality is complex, not black and white. At the most, he can present the preference of one way over another. The orator must choose one of two methods: either to make his stance clear, or to speak out against accepted opinions. An essential condition for the orator's success is the simple, clear transferral of the message. ${ }^{11}$ Nonetheless, to attract maximum attention, he needs to surprise and to bring new ideas.

\section{The Limits of the Rhetorical Unit}

In what follows I adopt the widespread view that regards Jeremiah 7: $1-15$ as a closed unit. This can be shown by the coherent structure and content of this unit. ${ }^{12}$ It is a well-organised, skilfully-crafted speech and its various parts are logically interrelated as will be shown below.

\section{The Type of Jeremiah's Speech}

According to Aristotle, there are three types of oratory: the deliberative, the forensic, and the epideictic. ${ }^{13}$ Jeremiah's speech should be classified as deliberative, as it attempts to persuade its audience to adopt an attitude or make a decision regarding actions in the future. Deliberative chiefly relies on ethos - the moral character of

11 Ch. Perelman and L. Olbrechts-Tyteca, The New Rhetoric and the Humanities. Essays on Rhetoric and its Applications (Dordrecht: D. Reidel, 1979): 503.

12 See C. D. Isbell and M. Jackson, 'Rhetorical Criticism and Jeremiah vii 1-viii 3', VT 30 (1980): 20-26; Lundbom, Jeremiah 1-20: 454-59; S. Zalewski, 'The Discourse of Jeremiah in the Gate of the House of the LORD (Jer. 7:1-15)', Bar-Ilan Annual 1617 (1979): 9-31 ( Hebrew).

13 On the definition of deliberative rhetoric, see Kennedy, New Testament Interpretation: $36-37,144-52$. 
the orator. ${ }^{14}$ The orator, according to Aristotle, must give the right impression of himself. It is especially relevant for Jeremiah's speech: He tries to convince the people of Judah that he knows exactly what he is talking about. Jeremiah's authority to speak comes directly from God. He is the true messenger of the LORD, an argument that is backed up by the formula 'thus says the Lord'. This statement aims to create trust between himself and his audience. ${ }^{15}$

\section{The Rhetorical Situation}

According to Kennedy, the second stage of rhetorical criticism is discerning the rhetorical situation. This includes the cause of the text, the reason it was written. ${ }^{16}$ Gitay writes similarly that 'The rhetorical situation is the cause of the speech; the situation which gave birth to the prophetic response.' ${ }^{17}$ What is the rhetorical situation in Jeremiah's speech? It seems that two specific groups were of special interest in Jeremiah's speech.

\subsection{Priests}

The reference to the Ten Commandments and to Shiloh implies the priests. ${ }^{18}$ It is the priests' task to teach the people how to keep the Ten Commandments (e.g. Deut. 17:9-12; 33:10; 2 Chr. 15:3; Jer. 2:8; 18:18; Ezek. 7:26; Hos. 5:1; Mal. 2:7). Since they fail to do this, they deserve to be censured, and the true prophets take the task upon

14 Aristotle, Rhetoric: 1356a, 1377b; Kennedy, New Testament Interpretation: 15; Gitay, Prophecy and Persuasion: 37.

15 Cf. Corbett, Classical Rhetoric for the Modern Student: 94; Kennedy, New Testament Interpretation: 15. See further J. F. Ross, 'The Prophet as Yahweh's Messenger', in Israel's Prophetic Heritage: Essays in Honor of James Muilenburg, ed. B. W. Anderson and W. Harrelson (London: SCM, 1962): 98-107, esp. 101. On viewing the prophets as messengers see S. A. Meier, The Messenger in the Ancient Semitic World (HSM, 45; Atlanta, GA: Scholars, 1988); J. T. Greene, The Role of the Messenger and Message in the Ancient Near East (Brown Judaic Studies, 169; Atlanta, GA: Scholars, 1989).

16 Kennedy, New Testament Interpretation: 36.

17 Y. Gitay, 'Reflections on the Study of the Prophetic Discourse: The Question of Isaiah 1:2-20', VT 33 (1983): 207-21, esp. 220. See also L. F. Bitzer 'The Rhetorical Situation', Philosophy and Rhetoric 1 (1968): 1-14.

18 Cf. M. Leuchter, 'The Temple Sermon and the Term מקום in the Jeremianic Corpus', JSOT 30 (2005): 93-109, esp. 104, n. 35. 
themselves. ${ }^{19}$ According to the description in 1 Samuel 2, Eli's sons, the priests, were responsible for the destruction of Shiloh. The priests' abuse of their position in Jeremiah's time is likely to cause the destruction of Jerusalem.

Jeremiah is particularly entitled to say this as, according to the first verse of the book (Jer. 1:1), he was from a priestly family. He knows very well how a priest is supposed to behave, and is therefore in a position to criticise. ${ }^{20}$

\subsection{False Prophets}

Jeremiah appears to be addressing a second group in his speech - the false prophets. They are indicated by the expression 'we are saved' and by the word 'falsehood'. The use of slogans implies the false prophets. ${ }^{21}$ The fact that the prophets and the priests were Jeremiah's leading accusers in the story of his trial in chapter 26 is also an indication that they understood Jeremiah's words perfectly.22

If Jeremiah's speech was indeed made in the year 609-608 BC, as many scholars suppose, ${ }^{23}$ it goes without saying that the effect created

19 Cf. R. B. Y. Scott, 'Priesthood, Prophecy, Wisdom, and the Knowledge of God', JBL 80 (1961): 1-15, esp. 3-4; Overholt, The Threat of Falsehood: A Study in the Theology of the Book of Jeremiah (Naperville, IL: SCM, 1970): 14; J. T. Willis, 'Ethics in a Cultic Setting', in Essays in Old Testament Ethics: J. Philip Hyatt, in Memoriam, ed. J. L. Crenshaw and J. T. Willis (New York: Ktav, 1974): 145-69.

20 In Zevit's opinion, the prophets did not speak out against the priests' ritual tasks. Their presentation as partners to the false prophets at most emphasised the deception through which the false prophets mislead them. However, the extent to which Zevit's opinion is incorrect is apparent from this speech in particular. See Z. Zevit, 'The Prophet versus Priest Antagonism Hypothesis: Its History and Origin', in The Priests in the Prophets: The Portrayal of Priests, Prophets and Other Religious Specialists in the Latter Prophets, ed. L. L. Graabe and A. O. Bellis (London: T. \& T. Clark, 2004): 189-217. Jeremiah speaks a lot about the cooperation between the prophets and the priests. See e.g. Jer. $2: 8 ; 4: 9 ; 5: 31 ; 6: 13 ; 8: 10$, and for further details Overholt, The Threat of Falsehood.

21 S. Zalewski, 'The Discourse of Jeremiah'.

22 On the relationship between Jeremiah 7 to Jeremiah 26, see Holt, 'Jeremiah's Temple Sermon'; K. M. O'Connor, "'Do not trim a word": The Contributions of Chapter 26 to the Book of Jeremiah', $C B Q 51$ (1989): 617-30; T. Seidl, 'Jeremias Tempelrede: Polemik gegen die joschijanische Reform? Die Paralleltraditionen Jer 7 und 26 auf ihre Effizienz für das Deuteronomismusproblem in Jeremia befragt', in Jeremia und die 'Deuteronomistische Bewegung', ed. W. Gross (Weinheim: Beltz Athenäum, 1995): 141-79.

23 See e.g. Holladay, Jeremiah, vol. 1 (Hermeneia Series; Minneapolis: Fortress, 1986): 240. In light of the numerous emphases on the covenant, it is possible that it is referring to the festival of Weeks. It may be possible to learn from $2 \mathrm{Chr} \cdot 15: 10-14$ that the festival of the renewal of the covenant is the festival of Weeks. See e.g. M. 
by Jeremiah was fear. That was a particularly difficult year for the people of Judah - a year full of turmoil: the death of Josiah; the replacement of two additional kings - Jehoahaz and Jehoiakim. Judah came under Egyptian rule, ${ }^{24}$ and the people sought comfort and security in the temple. Jeremiah's role was to destroy this feeling of calm and security. This period is most suitable for the false prophets to express their ideology and to gain popularity from the people. It is in this troubled era that Jeremiah had to stand still and go out against these prophets.

\section{The Arrangement of the Material}

Inventio ('invention') is one of the terms Aristotle used (Rhetoric: 1356a) to characterise the parts of the rhetorical process. ${ }^{25}$ Many scholars have identified the importance of the sequence of events in the plots of various stories. ${ }^{26}$

Menachem Perry writes that:

The literary text, like any verbal text, is received by the reader through a process of 'concretization'. Its verbal elements appear one after another, and its semantic complexes (e.g. scenes, ideas, characters, plot, valuejudgements) build up 'cumulatively', through adjustments and readjustments. That a literary text cannot yield its information all at once is not just an unfortunate consequence of the linear character of language.

Weinfeld, 'Pentecost as Festival of the Giving of the Law', in idem, Normative and Sectarian Judaism in the Second Temple Period (London: T. \& T. Clark, 2005): 26878, esp. 269.

24 Cf. B. Uffenheimer, Classical Prophecy: The Prophetic Consciousness (Hebrew; Jerusalem: Magnes, 2001): 281. For the historical background see Abraham Malamat, History of Biblical Israel: Major Problems and Minor Issues (CHANE 7; Leiden: Brill, 2001): chs. 15-17, pp. 282-337.

25 Kennedy, New Testament Interpretation: 23; J. M. Lauer, Invention in Rhetoric and Composition (West Lafayette, IN: Parlor, 2004): 6.

26 M. Perry, 'How the Order of a Text Creates its Meanings', Poetics Today 1 (1979): 35-64, 311-61, esp. 35; M. Sternberg, Expositional Modes and Temporal Ordering in Fiction (Baltimore: Johns Hopkins University, 1978): 34, 96-97; idem, 'Time and Reader', in The Uses of Adversity: Failure and Accommodation in Reader Response, ed. E. Spolsky (Lewisburg, PA: Bucknell University, 1990): 49-89, esp. 50-51, 77-78, 85; Gitay, Prophecy and Persuasion: 38-39. 
In contrast to Isaiah 1, in which grave accusations are brought against the people in the introduction, ${ }^{27}$ Jeremiah opens the body of his speech on a positive note: 'Amend your ways and your doings, and let me dwell with you in this place' (v. 3). This positive attitude is part of Jeremiah's ethos: he is really concerned with the destiny of Israel and he makes efforts to save them from errors.

Jeremiah 7 is a classic call for repentance - for a change of direction. Indeed, the land of Israel belongs to the people of Israel according to the promise made to the forefathers; but their dwelling in it is conditional: in every generation, the people have to prove that they are worthy of the land, and they should therefore take care that the temple does not become a source of illusion - a stumbling block for Israel. Later on, Jeremiah states that society has a moral obligation towards its members, and is therefore required to make improvements. From a rhetorical point of view, Jeremiah begins by moving from the general to the particular, and then returns to the general in the conclusion.

When Jeremiah sees no positive reaction from the audience, he raises his tone. As Aristotle (Rhetoric: 1408a) states: 'Emotion is expressed if the style, in the case of insolence, is that of an angry man; in the case of impious and shameful things.' He abandons all pretence and starts to express the full severity of his words. He begins his speech with a positive tone, but when this receives no response, he moves on to a description of the people's terrifying position. Evidence for this can be found in the prophet's speech (v. 13): 'When I spoke to you persistently, you did not listen.'

Jeremiah is now wearing the cloak of the prosecution in court. He presents the charges to the people followed by the consequences should they be found guilty. Jeremiah pleads that the people's negative behaviour constitutes a violation of the binding legal document that lays down the terms of the relationship between the people of Israel and God: the Ten Commandments. The Ten Commandments are defined as a covenant - a contract signed between Israel and God on Mount Sinai (Exodus 19-20), which obligates both sides. If the people break their side of the agreement, then God will break his. ${ }^{28}$

Jeremiah refers to the Ten Commandments in a different order from the way they appear in the Hebrew Bible. In Exodus 20, the religious

27 On the rhetorical function of the introduction in Isaiah 1, see Y. Gitay, 'Prophetic Discourse': 218.

28 Cf. Overholt, The Threat of Falsehood: 15. 
commandments come first, and the social commandments come afterwards. Jeremiah, however, starts by presenting the social commandments. Martin Buber explains the significance of this: ${ }^{29}$

The sins against religion come at the end (as in v. 6), because the prophet has to proclaim just this, that God seeks something other than religion. Out of a human community He wills to make his kingdom; community there must be in order that his kingdom shall come; therefore here, where he blames a people for not having become a community, man's claim upon man takes precedence of God's claim.

From here, the moral commandments occupy a more important position within the prophet's value-system. However, this opinion seems inappropriate to the book of Jeremiah, which names idolatry as the main reason for the destruction of the temple. Thus reads Jeremiah 9:12-14, for example:

Who is wise enough to understand this? To whom has the mouth of the LORD spoken, so that they may declare it? Why is the land ruined and laid waste like a wilderness, so that no one passes through? And the LORD says: Because they have forsaken my law that I set before them, and have not obeyed my voice, or walked in accordance with it but have stubbornly followed their own hearts and have gone after the Baals, as their ancestors taught them. (See also Jer. 5:10-11, 16, 18.)

What is special about Jeremiah's words is that he raises the position of social ethics to the level of an additional basic condition for the existence of the nation in its land, in contrast to the viewpoint that sees the temple sacrifices as the essence.

Apart from that, the distinction between 'man's claim' and 'God's claim' is problematic. The Hebrew Bible makes a connection between sins against man and sins against God. 'You shall not commit adultery' is not only a sin against man, but is also a sin against God. This is also the case with 'You shall not murder.' 30

It can be seen from here that progression is incorporated within Jeremiah's words. Amit defines the progression thus:

29 M. Buber, The Prophetic Faith, tr. C. Witton-Davies (New York: Harper, 1960): 172. For different explanations of this phenomenon, see e.g. M. Weiss, The Bible From Within: The Method of Total Interpretation (Jerusalem: Magnes, 1984): 256-59; Holladay, Jeremiah, 1: 244.

30 See J. H. Tigay, 'Adultery', Encyclopedia Judaica (Jerusalem: Keter; New York: Macmillan, 1972), 2:313-15. One may cite in this regard the David and Bathsheba affair (2 Sam. 11-12) as well. See M. Avioz, 'The Analogies between the DavidBathsheba Affair and the Naboth Narrative', JNSL (forthcoming). 
Progression, then, is a rhetorical technique, or contrivance, that organises the data for the author in a multi-phased, hierarchical structure, wherein the elements are arranged in an ascending or descending order: from the general to the particular, or vice versa; from minor to major, or the reverse ... ${ }^{31}$

In verses 3-5, we have seen the move from the general to the particular. Now we are seeing the progression from the (relatively) light to the serious. Jeremiah wishes to say this: "Not only have you sinned in a moral context, you have also dared to commit the greatest sin of all idolatry. 32

\section{Stylistic Devices}

\subsection{Citations and Refutation}

According to Aristotle, another line of argument is to refute your opponent's case by noting any contrasts or contradictions of dates, acts, or words (Rhetoric: 1391b; 1401b; 1416a). In this regard, Jeremiah quotes his antagonists' words, the false prophets: 'The temple of the LORD, the temple of the LORD, the temple of the LORD', (v. 4$)^{33}$ and again, 'we are saved' (v. 10). ${ }^{34}$ Presentation of the antagonists' words as slogans enables the audience to discern the untruths, ${ }^{35}$ as they ask themselves, 'What is the basis for this belief'?

Moreover, according to one of the definitions of falsehood, these are words spoken with the intention of creating an erroneous belief or understanding among the audience. ${ }^{36}$ It is done using half-truths and by delivering partial information. ${ }^{37}$

31 Y. Amit, 'Progression as a Rhetorical Device in Biblical Literature', JSOT 28 (2003): 3-32, esp. 9.

32 Cf. Zalewski, 'The Discourse of Jeremiah': 20, n. 38.

33 For an explanation of this difficult verse, see e.g. W. L. Holladay, Jeremiah, 1: 242

34 Overholt notes that there are about one hundred quotations in the book of Jeremiah. See T. W. Overholt, 'Jeremiah 2 and the Problem of "Audience Reaction", $C B Q 41$ (1979): 262-73, esp. 262.

35 One of the characteristics of a false expression is the use of slogans or short, unclear sentences. See M. L. Knapp, R. P. Hart \& H. S. Dennis, 'An Exploration of Deception as a Communication Construct', Human Communication Research, vol. 1 (1974): 15-29.

36 Anne Reboul, 'The Description of Lies in Speech Acts Theory', in Pretending to Communicate, ed. H. Parret (Berlin: de Gruyter, 1993): 292-98; Dariusz Galasinski, 
From the words לכם לכם ('to your own hurt', v. 6), it can be understood that Jeremiah feels that the words are spoken by the false prophets who are aware that they are partially or completely incorrect.

Although it is very likely that Jeremiah is referring to the beliefs about Jerusalem's immunity that developed during Sennacherib's campaign to Judah (2 Kgs 18-20; Isa. 36-39), ${ }^{38}$ Jeremiah only hints at this story by using the Hebrew words with the roots בטח (meaning 'trust') and נצל (meaning 'save'). ${ }^{39}$ An explicit mention of the story of Jerusalem's deliverance is likely to conceal Jeremiah's intention of presenting Jerusalem as vulnerable to the enemy. ${ }^{40}$

The use of the first person plural, נצלנו ('we are delivered', JPS; 'we are safe', NRSV) is also deliberate. Jeremiah does not say 'God has saved us', but says 'we are delivered'. In other words, he disconnects God from the slogans created by his antagonists. The word is apparently a quotation of a slogan regularly used by the false prophets. ${ }^{41}$

Various scholars who dealt with the subject of falsehood noted that the aspiration to popularity must be included in the motives for lying. ${ }^{42}$ The belief in falsehood stems from the false prophets' authority in the eyes of the people, and from the comfort they derive from the optimistic message.

In chapter 7, Jeremiah has to speak out against such beliefs. He has to contend with prophecies that were particularly popular. They had

The Language of Deception: A Discourse Analytical Study (Thousand Oaks, CA: Sage Publications, 2000).

37 M. L. Knapp \& M. E. Comadena, 'Telling It Like It Isn't: A Review of Theory and Research on Deceptive Communications', Human Communication Research, vol. 5 (1979): 270-85.

38 See the literature mentioned in T. W. Overholt, The Threat of Falsehood: 8, n. 17.

39 On the root בטח see J. W. Olley, "Trust in the Lord": Hezekiah, Kings and Isaiah', TynBul 50 (1999): 59-77. On the root נצל בה הennacherib's campaign, see Overholt, The Threat of Falsehood: 16.

40 In other parts of the book, the prophet also avoids hinting at subjects that are likely to be detrimental to his goals. For example, he avoids the use of the word 'dream' when referring to his prophetic call (Jer. 1), since this may cause the people to claim that there is no difference between him and the false prophets. See Ruth Fidler, 'Dreams Speak Falsely'? Dream Theophanies in the Bible: Their Place in Ancient Israelite Faith and Traditions (Hebrew; Jerusalem: The Hebrew University, 2005).

41 See S. Zalewski, “'And Say we are safe" as God's Reply in the Mouth of the Prophets and Jeremiah's Conflict', in Shalom Sivan Festschrift, ed. A. Even Shoshan et al. (Hebrew; Jerusalem: Qiryat Sepher, 1980): 197-206

42 C. V. Ford, Lies! Lies! Lies! The Psychology of Deceit (Washington, DC: American Psychiatric, 1999). 
been presented by prophets claiming to be God's messengers, representing the Zion tradition. ${ }^{43}$ This ideology seeks to highlight God's unconditional commitment to Jerusalem and to the temple while freeing the people from their commitment to God. According to Jeremiah, there is no guarantee that the temple will be saved, as it is not independent because of earlier promises; but rather depends upon the behaviour of the people.

Will he succeed in achieving the impossible and persuade the people that he is in the right? Jeremiah needs to persuade the people gathered at the temple that it is indeed an important place, ${ }^{44}$ and before coming to pray there, or to offer sacrifices, they must make sure that their hands are clean and must mend the error of their ways. Otherwise, they have no business to be in the temple, and it will not serve as their insurance against enemies who try to conquer the city. ${ }^{45}$

It seems that Jeremiah did not intend to speak against the legitimacy of the temple as such. His intention was to shock and to spur action. Other prophets worked in a similar way. They, too, did not speak out against the temple or religious rituals as such, but against the contempt towards the covenant that exists between the people and their God. ${ }^{46}$

43 The so-called 'Zion Tradition' is found mainly in the book of Psalms (see Ps. 46, 48,76 ) and in Isaiah. Of particular interest is Lam. 4:12: 'The kings of the earth did not believe, or any of the inhabitants of the world, that foe or enemy could enter the gates of Jerusalem' (RSV). See B. D. Ollenburger, Zion, City of the Great King (JSOTSup 41; Sheffield: JSOT, 1987); J. D. Levenson, 'Zion Tradition', ABD VI (1992): 10981102; S. E. Gillingham, 'The Zion Tradition and the Editing of the Hebrew Psalter', in Temple and Worship in Biblical Israel, ed. John Day (JSOTSup 422; London: T. \& T. Clark, 2005): 308-41, and the bibliography mentioned there. According to Ollenburger (Zion, 75), 'The development of Zion as a symbol of refuge is most likely associated ... with the Ark sanctuary as a place of refuge.'

44 On the multiple meanings of the word מקום in Jeremiah's speech, see D. Vanderhooft, 'Dwelling Beneath the Sacred Place: A Proposal for Reading 2 Samuel 7:10', JBL 118 (1999): 625-33, esp. 632.

45 Cf. Gordon McConville, 'Jerusalem in the Old Testament', in Jerusalem Past and Present in the Purposes of God, ed. P. W. L. Walker (Cambridge: Tyndale House, 1992):

Its message is that, contrary to the people's evident expectation, Yahweh's commitment to Jerusalem and its people is not a blind guarantee, nor can it be cultivated by an attention, however fastidious, to ritual worship alone. The mere intoning 'This is the Temple of the LORD, the Temple of the LORD, The Temple of the LORD' (v. 4) avails nothing if the weightier matters of the law are neglected. (37)

46 See recent study by B. D. Bibb, 'The Prophetic Critique of Ritual in Old Testament Theology', in The Priests in the Prophets, ed. L. L. Grabbe and A. Ogden Bellis (JSOTSup 408; London: T. \& T. Clark, 2004): 31-43; J. Barton, 'The Prophets and the Cult', in The Priests in the Prophets: 111-22; idem, Understanding Old Testament 


\subsection{The Rhetorical Questions}

Jeremiah presents the violation of the Ten Commandments as a rhetorical question: 'Will you steal, murder, commit adultery ...?' (v. 9). This is a confirmed rhetorical medium: the rhetorical question forces one answer on the audience, and in this case, it is negative. ${ }^{47}$ Aristotle (Rhetoric: 1419a) deals with the various uses of questions in a speech: 'Another situation is when [the speaker] intends to show that [the opponent] is contradicting himself or saying something paradoxical. ${ }^{48}$

In Brueggemann's opinion, Jeremiah uses rhetorical questions to speak out against accepted opinions, or to rephrase the answer to these questions ${ }^{49}$ The rhetorical questions are designed to make the audience utter such responses as: 'What are you talking about? Of course we won't violate all the Ten Commandments and then come to the Temple to pray.'

Jeremiah continues with a stronger rhetorical question: 'Has this house, which is called by my name, become a den of robbers?' (v. 11). This is a very strong expression, and there is no doubt that it outraged the audience. Its significance is that the temple has become a hiding place for criminals, thieves and murderers: a city of refuge for people who are not entitled to flee there. Jeremiah's audience would consider such a pronouncement to be a desecration of holiness.

Jeremiah is playing on the emotions here, and his words fit the pathos of Aristotle's rhetoric. The purpose of playing on the emotions in a speech is to affect the audience's judgement, and to make them identify with the orator's content. ${ }^{50}$

Ethics: Approaches and Explorations (Louisville, KY: Westminster/John Knox, 2003). For the view that Jeremiah goes against the temple, see G. Fischer, 'Zur Relativierung des Tempels im Jeremiabuch', in L'Écrit et l'esprit: Études d'histoire du texte et de théologie biblique en hommage à Adrian Schenker, ed. D. Böhler, I. Himbaza, and P. Hugo (OBO 214; Fribourg: Academic; Göttingen: Vandenhoeck \& Ruprecht, 2005): 87-99. I would like to thank Prof. Georg Fischer from the University of Innsbruck for providing me with a copy of his paper.

47 On rhetorical questions in the book of Jeremiah, see W. Brueggemann, 'Jeremiah's Use of Rhetorical Questions', JBL 92 (1973): 358-74. See also M. Held, 'Rhetorical Questions in Ugaritic and Biblical Hebrew', EI 9 (1969): 71-79; Lundbom, Jeremiah 1-20: 130-32.

48 Aristotle, On Rhetoric: A Theory of Civic Discourse, trans. G. A, Kennedy (Oxford: Oxford University, 1991): 279.

49 Brueggemann, 'Rhetorical Questions': 358.

50 Kennedy, On Rhetoric: 122-24. 


\subsection{Analogies}

Perelman and Olbrechts-Tyteca ${ }^{51}$ list a number of methods used by the orator to persuade his audience: comparison, demonstration and analogy, among others. The use of analogy is part of Aristotle's logos the appeal to reason. Like every successful rhetorician, Jeremiah has to prove his words. It is not enough to reject widespread conceptions. $\mathrm{He}$ must back up his arguments with the help of examples from history, as Aristotle writes: 'Examples are most suitable to deliberative speeches; for we judge of future events by divination from past events' (Rhetoric: 1368a; cf. 1418a).

Jeremiah needs to suggest opposing precedents to those brought by the false prophets. He notes two historical precedents.

The first example is the destruction of Shiloh (vv. 12-14). Before Jeremiah reaches the description of the Jerusalem temple's fate, he uses a series of relative clauses, rather than saying directly that the temple will be destroyed. 'The temple', indicating Jerusalem, is placed at the beginning of the sentence; and 'Shiloh', which constitutes the negative precedent, is placed at the end. Between them are placed the descriptions of the temple in Jerusalem:

... Therefore $I$ will do to the house that is called by my name, in which you trust, and to the place that I gave to you and to your ancestors, just what I did to Shiloh (v. 14).

Jeremiah combines past, present and future in one sentence: the temple belongs to God; he gave it to the people and to their forefathers. The people currently trust in him. God will do to it what he has already done to another temple - to Shiloh. This negative activity contradicts Jeremiah's demands in the first part of the speech - 'if you truly act justly' (v. 5) - but it is apparent from verses 10 and 13 that the people's actions are mainly negative.

What is the significance of the analogy to Shiloh? Jeremiah says: just as the ark of the covenant was to no avail in the days of Samuel and Eli because the priests had greatly sinned, so the temple in Jerusalem will be to no avail and will not protect the people, because they have not seen the error of their ways. ${ }^{52}$ The linkage between

51 Perelman and Olbrechts-Tyteca, The New Rhetoric: 371-93. Cf. also Holladay, Jeremiah, 1: 244 - 'the diction here is striking and emotional'.

52 See J. T. Willis, 'Samuel versus Eli: I Sam. 1-7', ThZ 35 (1979): 201-12, esp. 212;

J. Day, 'The Destruction of Shiloh Sanctuary and Jeremiah vii 12, 14', in Studies in the 
Shiloh and Jerusalem also appears in Psalm 78, although Jeremiah presents an opposing viewpoint to that of the psalm. Instead of presenting the difference between Jerusalem, which was chosen by God, and Shiloh, which was rejected by him, Jeremiah presents a direct parallel between the two towns: their citizens have sinned, and they will therefore receive a similar fate..$^{53}$

Jeremiah's words are considered to be innovational in relation to other prophets. Isaiah, for example, never once mentioned the possibility of the temple's destruction. He spoke about exile, but not about the destruction of the temple.

The second precedent, with which Jeremiah ends his speech (v. 15) relates to the destruction of the northern kingdom, when the ten tribes were exiled. Why? Because they committed the sins against which the prophet warned, and did not pay heed to their contemporary prophets' advice (see $2 \mathrm{Kgs}$ 17:13-14). That being the case, the people have no insurance: no temple and no divine promise that they will dwell in the land of Israel to eternity.

Jeremiah concludes his speech with a severe undertone: the threat of the destruction of the temple and exile. Throughout all the periods of Israel's history, exile was a substantive threat: the loss of property and independence, and life in a foreign land. In the eyes of the people, the

Historical Books of the Old Testament, ed. J. A. Emerton (VTSup 30; Leiden: Brill, 1979): 87-94, esp. 94; F. E. Deist, 'The Implied Message of the Reference to Shiloh in Jeremiah 7:12', Journal of Semitics 5 (1993): 57-67; P. Pitkänen, Central Sanctuary and Centralization of Worship in Ancient Israel: From the Settlement to the Building of Solomon's Temple (Piscataway, NJ: Gorgias, 2003): 124, and the literature mentioned there. Sharp, Prophecy and Ideology: 49 claims that Jeremiah is not referring to the destruction of Shiloh, but to God leaving his temple as a preliminary stage before the destruction of the temple. However, this viewpoint fits Ezek. 8-11, not Jer. 7.

53 See A. Frisch, 'Jerusalem and Its Parallels: Five Cities Paired with Jerusalem in the Bible', Abr-Nahrain 32 (1994): 80-95; W. Brueggemann, A Commentary on Jeremiah: Exile and Homecoming (Grand Rapids: Eerdmans, 1998): 8. On the linkage between Jeremiah 7 and Psalm 78, see E. Haag, 'Zion und Schilo. Traditionsgeschichtliche Parallelen in Jeremia 7 und Psalm 78', in Die alttestamentliche Botschaft als Wegweisung: Festschrift für Heinz Reinelt, ed. J. Zmijewski (Stuttgart: Katholisches Bibelwerk, 1990): 85-115. According to Adele Berlin, the psalmist is dependent on Jeremiah. See 'Psalms and the Literature of Exile: Psalms 137, 44, 69, and 78', in The Book of Psalms: Composition and Reception, ed. P. W. Flint and P. D. Miller, Jr. (Leiden: Brill, 2005): 65-86. However, this can be possible only if we assume a late date for Psalm 78. I am inclined to assign an earlier, tenth century BC date for that psalm. See A. F. Campbell, 'Psalm 78: A Contribution to the Theology of Tenth Century Israel', $C B Q 41$ (1979): 51-79. 
destruction of the temple meant losing their intimate connection with God, and living in an impure land.

\section{What Was Not Mentioned in the Speech?}

The comparison of the speech in Jeremiah 7 with other speeches reveals that the prophet passed over an important element in his speech: the kings of the house of David. ${ }^{54}$ In Isaiah 28 , for example, the prophet does mention it, as Roberts notes: ${ }^{55}$

Jerusalem's security is dependent on Yahweh's presence in the city. However, that presence depends on the religious and just behavior of the human inhabitants of Jerusalem, particularly that of the king and his officials ...

In Jeremiah's speech, he also discusses the question of Jerusalem's protection of her citizens, but he does not specifically mention the kings of the house of David. This is in spite of the fact that the treatment of orphans, poor people and widows is part of the king's responsibility (see for example Ezek. 22:6-7; cf. 25; 29; Ps. 72:4; Prov. 23:10-11). ${ }^{56}$ Two possible reasons can be suggested for why Jeremiah did not mention the kings of the house of David in his prophecy. First, they are referred to in different prophecies (particularly in Jer. 21-24). Secondly, specific mention of the kings of the house of David would have been likely to shift the focus from the discussion of the temple and its functions, to the fate of the promise made to the house of David that it will be an everlasting kingdom. The promise could have been used by the false prophets, claiming that not only is the temple protected, but Jerusalem is also protected - not only because of the divine presence within her, but also because of the promise made to

54 In my opinion, Overholt's attempt to link Jeremiah 7 with the king is forced (The Threat of Falsehood: 10).

55 J. J. M. Roberts, 'Yahweh's Foundation in Zion (Isa 28:16)', JBL 106 (1987): 45; emphasis added.

56 F. C. Fensham, 'Widow, Orphan, and the Poor in Ancient Near Eastern Legal and Wisdom Literature', JNES 22 (1962): 129-39; R. D. Patterson, 'The Widow, Orphan, and the Poor in the Old Testament and the Extra-Biblical Literature', BibSac 130 (July 1973): 223-34; K. W. Whitelam, The Just King: Monarchical Judicial Authority in Ancient Israel (JSOTSup, 12; Sheffield: JSOT, 1979); M. Weinfeld, Social Justice in Ancient Israel and in the Ancient Near East (Jerusalem: Magnes; Minneapolis: Fortress, 1995); H. V. Bennett, Injustice Made Legal: Deuteronomic Law and the Plight of Widows, Strangers, and Orphans in Ancient Israel (Grand Rapids: Eerdmans, 2002). 
David in 2 Samuel $7 .{ }^{57}$ By excluding specific mention of the kings of the house of David, Jeremiah can refer the legal demand for protection of the weak to society as a whole, as is done in the Pentateuch. This is also the apparent reason for Jeremiah's deviation from the line presented in Psalm 78: instead of ending with the choice of David for the monarchy, he concludes with threats about the destruction of the temple and the exile of the people from their land.

\section{Summary and Conclusions}

This study attempted to show that a rhetorical analysis of Jeremiah helps to clarify the different parts of the speech correctly; to discover what was mentioned and what was not mentioned in it; and to identify the methods of persuasion used by the prophet. This is not merely a literary analysis of the speech, but primarily a critical examination of how Jeremiah planned to deliver his words to the audience. My analysis concludes that Jeremiah's speech is planned and well organised, and that all its parts logically interconnect. Jeremiah uses many traditions from the past, and on the basis of these traditions, presents new arguments. Jeremiah knows what to say and what not to say, and is justifiably defined by Lundbom thus: ${ }^{58}$

Jeremiah is seen to be ... well-trained in rhetoric of his day and surely perceived, by those who heard him, to be an engaging orator.

57 We can therefore reject Lundbom's opinion (Jeremiah 1-20: 471), who writes that the prophecies in chapter 7 'challenge the notion that Yahweh's eternal and unconditional covenant to David'. There are not enough hints in chapter 7 to connect this prophecy with the Davidic covenant in 2 Sam. 7. The main theme of Jer. 7 is the temple.

58 Lundbom, Jeremiah 1-20: 121. 